NASA/TM-2002-211557

\title{
Ice Accretions on a Swept GLC-305 Airfoil
}

Mario Vargas

Glenn Research Center, Cleveland, Ohio

Michael Papadakis

Wichita State University, Wichita, Kansas

Mark Potapczuk, Harold Addy, David Sheldon, and Julius Giriunas

Glenn Research Center, Cleveland, Ohio 
Since its founding, NASA has been dedicated to the advancement of aeronautics and space science. The NASA Scientific and Technical Information (STI) Program Office plays a key part in helping NASA maintain this important role.

The NASA STI Program Office is operated by Langley Research Center, the Lead Center for NASA's scientific and technical information. The NASA STI Program Office provides access to the NASA STI Database, the largest collection of aeronautical and space science STI in the world. The Program Office is also NASA's institutional mechanism for disseminating the results of its research and development activities. These results are published by NASA in the NASA STI Report Series, which includes the following report types:

- $\quad$ TECHNICAL PUBLICATION. Reports of completed research or a major significant phase of research that present the results of NASA programs and include extensive data or theoretical analysis. Includes compilations of significant scientific and technical data and information deemed to be of continuing reference value. NASA's counterpart of peerreviewed formal professional papers but has less stringent limitations on manuscript length and extent of graphic presentations.

- TECHNICAL MEMORANDUM. Scientific and technical findings that are preliminary or of specialized interest, e.g., quick release reports, working papers, and bibliographies that contain minimal annotation. Does not contain extensive analysis.

- CONTRACTOR REPORT. Scientific and technical findings by NASA-sponsored contractors and grantees.
- CONFERENCE PUBLICATION. Collected papers from scientific and technical conferences, symposia, seminars, or other meetings sponsored or cosponsored by NASA.

- SPECIAL PUBLICATION. Scientific, technical, or historical information from NASA programs, projects, and missions, often concerned with subjects having substantial public interest.

- TECHNICAL TRANSLATION. Englishlanguage translations of foreign scientific and technical material pertinent to NASA's mission.

Specialized services that complement the STI Program Office's diverse offerings include creating custom thesauri, building customized data bases, organizing and publishing research results ... even providing videos.

For more information about the NASA STI Program Office, see the following:

- Access the NASA STI Program Home Page at http://www.sti.nasa.gov

- E-mail your question via the Internet to help@sti.nasa.gov

- Fax your question to the NASA Access Help Desk at 301-621-0134

- Telephone the NASA Access Help Desk at 301-621-0390

- Write to:

NASA Access Help Desk

NASA Center for AeroSpace Information 7121 Standard Drive

Hanover, MD 21076 
NASA/TM-2002-211557

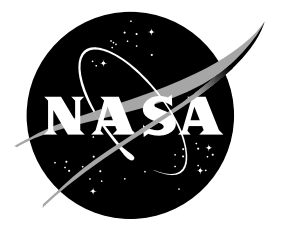

\section{Ice Accretions on a Swept GLC-305 Airfoil}

Mario Vargas

Glenn Research Center, Cleveland, Ohio

Michael Papadakis

Wichita State University, Wichita, Kansas

Mark Potapczuk, Harold Addy, David Sheldon, and Julius Giriunas

Glenn Research Center, Cleveland, Ohio

Prepared for the

General Aviation Technology Conference and Exhibition 2002

sponsored by the Society of Automotive Engineers

Wichita, Kansas, April 16-18, 2002

National Aeronautics and

Space Administration

Glenn Research Center 


\section{Acknowledgments}

The authors would like to thank Dr. James Riley and Mr. Eugene Hill for their guidance in all aspects of the experiment; the personnel at the Icing Research Tunnel; Mr. David Brinker for his help during the experiment; the personnel at WSU that participated in the design and fabrication of the airfoil; Mr. Chris Lynch for his assistance

with the photographic work; and Mr. Robert Reminder for his assistance with the fabrication of the castings.

Trade names or manufacturers' names are used in this report for identification only. This usage does not constitute an official endorsement, either expressed or implied, by the National Aeronautics and Space Administration.

Available from

NASA Center for Aerospace Information 7121 Standard Drive

Hanover, MD 21076
National Technical Information Service 5285 Port Royal Road Springfield, VA 22100 


\title{
Ice Accretions on a Swept GLC-305 Airfoil
}

\author{
Mario Vargas \\ National Aeronautics and Space Administration \\ Glenn Research Center \\ Cleveland, Ohio \\ Michael Papadakis \\ Wichita State University \\ Wichita, Kansas \\ Mark Potapczuk, Harold Addy, David Sheldon, and Julius Giriunas \\ National Aeronautics and Space Administration \\ Glenn Research Center \\ Cleveland, Ohio
}

\begin{abstract}
An experiment was conducted in the lcing Research Tunnel (IRT) at NASA Glenn Research Center to obtain castings of ice accretions formed on a $28^{\circ}$ swept GLC-305 airfoil that is representative of a modern business aircraft wing. Because of the complexity of the casting process, the airfoil was designed with three removable leading edges covering the whole span. Ice accretions were obtained at six icing conditions. After the ice was accreted, the leading edges were detached from the airfoil and moved to a cold room. Molds of the ice accretions were obtained, and from them, urethane castings were fabricated. This experiment is the icing test of a two-part experiment to study the aerodynamic effects of ice accretions.
\end{abstract}

\section{Introduction}

The experiment is part of a program by the Federal Aviation Administration, Wichita State University, and NASA (FAA/WSU/NASA) to study the aerodynamic effects of $3 D$ ice accretions. The objective is to develop an experimental database of ice accretion effects on the aerodynamic performance of finite swept wings. This work is needed because there is no publicly available, reference-quality database to provide an understanding of ice contamination effects for 3D ice accretions. This research will provide information on the nature of $3 D$ versus $2 D$ ice accretions and help regulatory authorities in determining compliance issues.

This report presents the results of an experimental investigation conducted in the Icing Research Tunnel at NASA Glenn Research Center to obtain castings of ice accretions formed on a swept GLC305 airfoil $^{1}$. The experiment is the first part (icing test) of a two-part experiment to study the aerodynamic effects of 3D ice accretions.

A $28^{\circ}$ swept GLC-305 airfoil was designed and fabricated. Its geometry is representative of a modern business aircraft wing. The airfoil was designed with three removable leading edges that together covered the full span of the airfoil. The airfoil was installed in the IRT and ice accretions were obtained at six icing conditions. The conditions were chosen to obtain ice accretions that were representative of the main types that have been observed in previous studies ${ }^{2,3,4}$ of ice accretions on swept wings. The ice accretions were documented photographically and tracings of the ice shapes were obtained at three locations. At each icing condition the leading edges with the ice accretions were detached from the airfoil and moved to a cold room adjacent to the tunnel. For each ice accretion, a mold was made in the cold room. At a later date a urethane casting was obtained.

The castings and the airfoil will be used for the second part of the experiment: aerodynamic performance measurements to be conducted at the Wichita State University (WSU) Beach Wind Tunnel in the spring of 2002.

\section{Experimental Procedure}

\section{Icing Research Tunnel}

Figure 1 shows the Icing Research Tunnel. The IRT is a closed-loop refrigerated wind tunnel with a test section 6 feet (1.8 meters) high, 9 feet (2.7 meters) wide and 20 feet (6.0 meters) long. The total air temperature in the test section can be varied between $-20{ }^{\circ} \mathrm{F}\left(-30{ }^{\circ} \mathrm{C}\right)$ and $+33^{\circ} \mathrm{F}\left(+1{ }^{\circ} \mathrm{C}\right)$ within $\pm 1{ }^{\circ} \mathrm{F}\left( \pm 0.5^{\circ} \mathrm{C}\right)$. Velocities up to $390 \mathrm{mph}$ $(174 \mathrm{~m} / \mathrm{s})$ can be obtained. A spray system allows control of the liquid water content (LWC) between 
0.2 to 3.0 grams per cubic meter. The spray nozzles provide droplet median volume diameters (MVD) from 15 to $40 \mu \mathrm{m}$.

\section{Model}

A GLC-305 swept airfoil was designed and built at WSU. Aerodynamic considerations and facility size limitations determined the overall size and geometry of the airfoil (figure 2). The airfoil has a constant GLC-305 section from root to tip, $28^{\circ}$ leading edge sweep, 5 foot semispan, aspect ratio of 6.80 , taper ratio of 0.4 , and geometric twist of $0^{\circ}$ at the root and $-4^{\circ}$ at the tip. The chord measures 25.2 inches at the root, and 10.08 inches at the tip. It is instrumented with 205 pressure ports distributed chordwise at 5 spanwise locations.

The casting procedure was limited to 25 inches maximum length per mold along the span of the airfoil. For this reason the airfoil needed to be designed and built with three removable leading edges (figure 3) that together covered the whole span of the airfoil. The removable leading edges were labeled Top, Middle and Bottom. The Top removable leading edge was the one at the tip of the airfoil, and the Bottom removable leading edge was at the root of the airfoil.

Because of the size of the airfoil with respect to the test section in the IRT, and the need to obtain the ice accretions where the icing cloud in the tunnel is uniform, the airfoil was designed to be placed in two positions in the tunnel: a low and a high position. In the low position (figure 3) the ice accretion on the removable leading edge near the tip was located at the optimal area of the icing cloud. In the high position (figure 4) the leading edges near the root of the airfoil and in the middle were located in the optimal area of the icing cloud.

Two icing runs at each icing condition were needed to obtain one complete ice accretion on the total span of the airfoil. The first run with the airfoil in the low position provided the ice accretion on the removable leading edge near the tip. In this position the ice accretions on the Middle and Bottom leading edges were not used. A second run with the airfoil in the high position provided the ice accretion on the removable leading edges at the root and the middle of the airfoil. In this position the ice accretion on the leading edge near the tip was not used. From the two airfoil positions (at a given icing condition) three removable leading edges with ice accretions were obtained and used to make a set of three molds, and later a set of three castings. Each icing condition resulted in a set of three castings representing the ice accretion along the whole span. Ultimately, six sets of castings were obtained during the test (one set for each of the six icing conditions) for a total of 18 castings.

\section{Test Procedure to Obtain the Ice Accretions}

At the start of each run, the tunnel was brought to the target velocity and total temperature, then the tunnel spray system was started. During the run the tunnel parameters were recorded using the NASA-Glenn Escort data acquisition system. Once the target ice accretion time was reached, the spray system was shut off, and the tunnel was brought to idle. After entering the tunnel, photographic data were taken with a $35-\mathrm{mm}$ camera following a predetermined sequence and location for the pictures. Cuts were then made on the ice accretion using a heated aluminum block to prepare the leading edges for removal and for pencil tracing. When the airfoil was placed in the low position only one cut (perpendicular to the leading edge) was needed, at the location where the Top and the Middle leading edges join. When the airfoil was placed in the high position three cuts were needed: one at the intersection where the Top and Middle leading edges join, another at the location where the Middle and Bottom leading edges join, and one at the lower part of the Bottom leading edge. The first two cuts were made perpendicular to the leading edge. The last one was parallel to the flow direction (streamwise direction) because it was located at the exact root of the airfoil. At each cut, a pencil tracing of the ice shape was made on a cardboard template. After the tracings were done, the leading edges were detached from the airfoil and moved to the cold room adjacent to the tunnel to begin the casting process.

\section{The Casting Process}

The casting process involved two steps: the making of the mold, and the making of the actual casting.

The process started when the leading edge was removed and taken to the cold room. The leading edge was placed inside a wood box (figure 5). To properly attach the leading edge to the box without damaging the ice accretion, the top and one side of the box were removed. Once the leading edge was attached to the inside of the box, the removed side of the box was reinstalled. The box was left open at the top for pouring in the mold material. Styrofoam pieces were placed around the ice 
accretion, without touching it, to reduce the quantity of mold material needed.

Preparation of the Dow Corning 3110 RTV mold material started before the tunnel runs. Dow 3110 was poured in containers and mixed with Dow Corning 200, 20 centistokes, at $10 \%$ of the Dow 3110 by weight. Each container was de-gassed for 30 minutes or more in a bell jar and then placed in a freezer. When the leading edge was ready inside the box, a container with Dow 3110 was removed from the freezer and Dow Corning No. 4 catalyst was added, at a 1/125 ratio of the Dow 3110 by weight. After mixing, it was de-gassed in the bell jar for 5 minutes, moved to the cold room and poured into the box containing the leading edge with the ice accretion. The mold was left to cure overnight. In the morning the mold was separated from the leading edge.

Once the molds were finished, they were moved to the Model Shop of NASA Glenn Research Center where the castings were made. To make a casting, each mold was placed inside the same box used to make it. The leading edge that was used to make the mold was placed in the same position as when the mold was made. A separation distance was left between the leading edge and the mold to create a thin wall for the casting. A polyurethane elastomer, Ciba-Geigy RP 6430 , was poured in and left to cure. After curing, the leading edge was separated from the casting, and the mold material was removed from around the casting.

Figure 6 shows a close-up picture of the casting obtained from the ice accretion shown in figure 23. Comparison of the two figures indicates the detail captured with the casting process.

\section{Test Matrix for Icing Runs}

Table 1 lists the six icing conditions chosen to obtain ice accretions representative of the main types observed on swept wings. Table 2 lists all of the runs done in the IRT to obtain ice accretions for the Top, Middle, and Bottom leading edges at each one of the six icing conditions.

\section{Results and Discussion}

Icing Condition 1: Complete Scallop Condition $\alpha=4^{\circ}, V=250 \mathrm{mph}, \mathrm{T}_{\text {total }}=25^{\circ} \mathrm{F}, \mathrm{LWC}=0.68$ $\mathrm{g} / \mathrm{m}^{3}, \mathrm{MVD}=\mathbf{2 0} \mu \mathrm{m}, \tau=10$ minutes
At this glaze ice condition the ice accretion on the Top leading edge (figure 7) shows well-defined scallop tips beginning at the attachment line. The space between the scallop tips shows some accumulation of ice. The scallop tips are covered with roughness elements. A side view of the ice accretion (figure 8) shows the feather formation of the scallop tips. Figure 9 shows an overall view of the ice accretion obtained at the Top removable leading edge. Figure 10 shows a front view and a side view of the casting from the ice accretion on the Top removable leading edge. The side view is of the pressure side of the airfoil. The casting shows how the ice accretion increases in size away from the tip of the airfoil. The ice accretions for the Middle and Bottom leading edges show the same characteristics as the one for the Top leading edge.

\section{Icing Condition 2: Incomplete Scallop Condition $\alpha=4^{\circ}, \mathrm{V}=150 \mathrm{mph}, \mathrm{T}_{\text {total }}=25^{\circ} \mathrm{F}$, LWC $=0.65 \mathrm{~g} / \mathrm{m}^{3}, \mathrm{MVD}=20 \mu \mathrm{m}, \tau=10$ minutes}

At this glaze ice condition the ice accretion on the Bottom leading edge (figure 11) shows scallop tips beginning at a given distance from the attachment line. The ice accretion is a typical incomplete scallop. A side view of the ice accretion (figure 12) on the suction side of the airfoil shows the scallop tips and their feather structure. The ice accretions for the Top and Middle leading edges show the same characteristics. Figure 13 shows an overall view of the ice accretion obtained at the Bottom leading edge. Figure 14 shows a front view and a side view of the corresponding casting from the ice accretion on the Bottom leading edge. The side view is of the pressure side of the airfoil.

Icing Condition 3: Scaled Condition $\alpha=6^{\circ}, V=$ $201.3 \mathrm{mph}, \mathrm{T}_{\text {total }}=11.7^{\circ} \mathrm{F}, \mathrm{LWC}=0.51 \mathrm{~g} / \mathrm{m}^{3}, \mathrm{MVD}$ $=14.5 \mu \mathrm{m}, \tau=5$ minutes

This icing condition was obtained by scaling a reference icing condition ${ }^{5}$ that had been tested on a 2D GLC-305 (chord = 3 feet) in the Low-Turbulence Pressure Tunnel (LTPT) at NASA Langley Research Center ${ }^{6}$. The scaled reference condition was: $A O A=$ $6^{\circ}$, Velocity $=201.3 \mathrm{mph}$, Total temperature $=11.7^{\circ} \mathrm{F}$, $\mathrm{LWC}=0.40 \mathrm{~g} / \mathrm{m}^{3}, \mathrm{MVD}=20 \mu \bullet \mathrm{m}, \tau=16.7$ minutes.

The ice accretion (figure 15) is a no-scallop. The side view (figure 16) of the ice accretion on the pressure side of the airfoil shows a feather structure. The ice around the attachment line is smooth with a pointed shape and a whitish color. This indicates that the ice accretion is of the rime type. Figure 17 shows an overall view of the ice accretion obtained at the 
Bottom removable leading edge. Figure 18 shows a front view and a side view of the casting from the ice accretion on the Bottom leading edge. The side view is of the suction side of the airfoil. The ice in the Top, Middle and Bottom leading edges show the same characteristics.

Icing Condition 4: Complete Scallop Condition $\alpha=4^{\circ}, \mathrm{V}=250 \mathrm{mph}, \mathrm{T}_{\text {total }}=25^{\circ} \mathrm{F}, \mathrm{LWC}=0.68$ $\mathrm{g} / \mathrm{m}^{3}, \mathrm{MVD}=20 \mu \mathrm{m}, \tau=2$ minutes

This icing condition was chosen to obtain data for a complete scallop case at a short ice accretion time. The only difference between this condition and Icing Conditions 1 and 5 is in the duration of the ice accretion time, 2 minutes versus 10 and 22.5 minutes, respectively. The ice accretion (figure 19) shows the presence of scallop tips. The scallop tips on the suction side are more developed than the scallop tips on the pressure side. Figure 20 shows the ice accretion on the suction side of the airfoil. The scallop tips with their feather formation can be observed. Figure 21 shows an overall view of the ice accretion obtained at the Middle removable leading edge. Figure 22 shows a front view and a side view of the casting from the ice accretion on the Middle leading edge. The side view is of the suction side of the airfoil.

Icing Condition 5: Complete Scallop Condition $\alpha=4^{\circ}, \mathrm{V}=250 \mathrm{mph}, \mathrm{T}_{\text {total }}=25^{\circ} \mathrm{F}, \mathrm{LWC}=0.68$ $\mathrm{g} / \mathrm{m}^{3}, \mathrm{MVD}=20 \mu \mathrm{m}, \tau=22.5$ minutes

This ice condition was selected to obtain the ice accretion for the complete scallop at a long ice accretion time. The castings from Icing Conditions 1 , 4 , and 5 allow studying for the complete scallop case the effect of the ice accretion time on aerodynamic performance. The ice accretion (figure 23) is a complete scallop similar to the one in Icing Condition 1 in general characteristics and shape, but larger in size. Figure 24 shows a side view of the ice accretion on the suction side of the airfoil. The scallop tips and their feather structure can be observed. Figure 25 shows an overall view of the ice accretion obtained at the Middle removable leading edge. Figure 26 shows a front view and a side view of the casting from the ice accretion on the Middle removable leading edge. The side view is of the pressure side of the airfoil.

When this icing condition was run with the airfoil in the low position, a piece of the ice accretion was consistently blown off the airfoil. For this reason the icing condition was run at a lower velocity $(225 \mathrm{mph})$ when the airfoil was in the low position. To maintain the same mass flux as in the case at $250 \mathrm{mph}$ the LWC was increased to $0.89 \mathrm{~g} / \mathrm{m}^{3}$. Photographic data from the ice accretion at $250 \mathrm{mph}$ and the one obtained at $225 \mathrm{mph}$ per hour indicated that the two ice accretions are very close in overall characteristics. Castings were made of the ice accretion obtained at $225 \mathrm{mph}, 0.89 \mathrm{~g} / \mathrm{m}^{3}$, for the Middle and Bottom leading edges; and at $250 \mathrm{mph}$, $0.68 \mathrm{~g} / \mathrm{m}^{3}$, for the Top leading edge.

Icing Condition 6: Ice Protection Failure Condition $\alpha=4^{\circ}, \mathrm{V}=150 \mathrm{mph}, \mathrm{T}_{\text {total }}=27^{\circ} \mathrm{F}$, LWC $=0.46 \mathrm{~g} / \mathrm{m}^{3}, \mathrm{MVD}=20 \mu \mathrm{m}, \tau=22.5$ minutes

This ice condition was chosen to obtain castings that will provide performance data for the case of 22.5 minutes ice protection failure. The condition was chosen to be within the FAA Federal Aviation Regulations (FAR) 25 Appendix C. The ice accretion (figure 27) shows the presence of scallop tips but they are not well defined. They seem to begin away from the attachment line, but this is not certain because glaze ice covers the area around the attachment line and the ice is not transparent enough to allow a determination about the presence of feathers around the attachment line area. A side view of the ice accretion (figure 28) shows the scallop tips formed by glaze ice feathers. Figure 29 shows an overall view of the ice accretion obtained at the Top removable leading edge. There is significant accumulation of ice on the actual tip of the airfoil. The ice accretion is non-uniform. The ice accretions on the Bottom and Middle leading edges show the same characteristics: not well defined scallop tips, and glaze ice covering the attachment line area made of glaze ice. Figure 30 shows a front view and a side view of the casting from the ice accretion on the Top leading edge. The side view is of the suction side. The photographic data and the castings show that there is significant accumulation of ice on the actual tip of the airfoil.

\section{Summary of Results}

An experiment was conducted to obtain castings from ice accretions formed on a $28^{\circ}$ swept GLC305 airfoil. Ice accretions and castings were obtained for six icing conditions.

Three of the conditions were selected to obtain complete scallops. The ice accretions in those cases showed the typical characteristics of complete scallops, well-defined scallop tips beginning at the attachment line and formed by glaze ice feathers. Castings were obtained for 2, 
10 and 22.5 minutes and they will allow the study of ice accretion times on aerodynamic performance for a complete scallop case.

One condition was run to obtain an incomplete scallop. The ice accretion in this case was an incomplete scallop with scallop tips beginning at a given distance from the attachment line.

Another condition was run to obtain data for the case of 22.5 minutes failed ice protection system. The condition was within the FAR 25 Appendix C. The ice accretion showed scallop tips that were not well defined, but it was difficult to determine if it was a complete or incomplete scallop.

One of the conditions run was a scaled condition from a $2 \mathrm{D}$ case. The ice accretion obtained was a rime ice no-scallop condition.

In general ice accumulation was observed at the actual tip of the airfoil.

The ice accretions obtained showed the same characteristics as ice accretions of the same type obtained in previous studies of ice accretion physics $^{2,3,4}$ conducted on a NACA 0012.

A total of 18 castings were obtained in the experiment, with three castings (Top, Middle and Bottom) for each icing condition. The castings from the present experiment together with the GLC-305 airfoil will be used to obtain aerodynamic performance data in the second part of the experimental investigation to be conducted at the WSU Beach Wind Tunnel in the spring of 2002. Once the two parts of the experimental investigation have been completed, they will constitute the first step in the development of a database of ice accretion effects on the aerodynamic performance of finite swept wings.

\section{Nomenclature}

$\begin{array}{ll}\Lambda & \text { Sweep angle, degrees } \\ A O A & \text { Angle of attack } \\ d_{c r} & \text { Critical distance, millimeters } \\ L W C & \text { Cloud liquid water content, } \mathrm{g} / \mathrm{m}^{3} \\ M A C & \text { Mean Aerodynamic Chord } \\ M V D & \text { Water droplet median volume diameter, } \\ & \mu \mathrm{m} \\ T_{\text {total }} & \text { Total temperature, }{ }^{\circ} \mathrm{F} \\ \tau & \text { Ice accretion time, minutes } \\ V & \text { Velocity, } \mathrm{mph}\end{array}$

\section{References}

\begin{abstract}
${ }^{1}$ Hinson, M. L., "A Series of Airfoils Designed by Transonic Drag Minimization for Gates Learjet Aircraft", Transonic Aerodynamics, edited by David Nixon, American Institute of Aeronautics and Astronautics, New York, 1982, pp. 489-509.
\end{abstract}

2 Vargas, M. and Reshotko, E., "Physical Mechanisms of Glaze Ice Scallop Formations on Swept Wings", AIAA Paper 98-0491, Jan. 1998. NASA TM-1998-206616.

${ }^{3}$ Vargas, M., "Ice Accretion on Swept Wings at Glaze Ice Conditions", Ph.D. Thesis, Case Western Reserve University, Cleveland, Ohio, May 1998.

4 Vargas, M. and Reshotko, E., "Parametric Experimental Study of the Formation of Glaze Ice Shapes on Swept Wings", AlAA Paper 99-0094, Jan. 1999. NASA TM-1999-208900.

${ }^{5}$ Personal communication between Dr. James T. Riley, Dr. Dave N. Anderson and Mr Harold E. Addy. Mr. Addy provided the reference icing condition. Dr. Anderson did the scaling from the reference condition.

${ }^{6}$ Addy, $\mathrm{H}_{\text {., }}$ "Ice Accretions and Icing Effects for Modern Airfoils". DOT/FAA/AR-99/89. NASA TP2000-210031. 


\begin{tabular}{|c|c|c|c|c|c|c|c|}
\hline Icing Condition \# & Description & $\begin{array}{c}\text { Angle of } \\
\text { Attack } \\
\text { (degrees) }\end{array}$ & $\begin{array}{c}\text { Velocity } \\
\text { (mph) }\end{array}$ & $\begin{array}{c}\text { Total } \\
\text { Temperature } \\
\left({ }^{\circ} \mathrm{F}\right)\end{array}$ & $\begin{array}{l}\text { LWC } \\
\left(\mathrm{g} / \mathrm{m}^{3}\right)\end{array}$ & $\begin{array}{l}\text { MVD } \\
(\mu \mathrm{m})\end{array}$ & $\begin{array}{l}\text { Ice Accretion } \\
\text { Time } \\
\text { (min) }\end{array}$ \\
\hline Icing Condition 1 & Complete Scallop Condition & 4 & 250 & 25 & 0.68 & 20 & 10 \\
\hline Icing Condition 2 & Incomplete Scallop Condition & 4 & 150 & 25 & 0.65 & 20 & 10 \\
\hline Icing Condition 3 & $\begin{array}{c}\text { Run based on scaled Condition } 2 \\
\text { for run in } 2 \mathrm{D} \text { table }\end{array}$ & 6 & 201.3 & 11.7 & 0.51 & 14.5 & 5.0 \\
\hline Icing Condition 4 & $\begin{array}{c}\text { Complete Scallop Condition short } \\
\text { ice accretion time }\end{array}$ & 4 & 250 & 25 & 0.68 & 20 & 2 \\
\hline Icing Condition 5 & $\begin{array}{l}\text { Complete Scallop Condition long } \\
\text { ice accretion time }\end{array}$ & 4 & 250 & 25 & 0.68 & 20 & 22.5 \\
\hline Icing Condition 6 & $\begin{array}{l}22.5 \text { minute failed ice protection } \\
\text { App C }\end{array}$ & 4 & 150 & 27 & 0.46 & 20 & 22.5 \\
\hline
\end{tabular}

Table 1. Selected Icing Conditions

\begin{tabular}{|c|c|c|c|c|c|c|c|}
\hline Run Number & Description & $\begin{array}{l}\text { Angle of } \\
\text { Attack } \\
\text { (degrees) }\end{array}$ & $\begin{array}{l}\text { Velocity } \\
\text { (mph) }\end{array}$ & $\begin{array}{c}\text { Total } \\
\text { Temperature } \\
\left({ }^{\circ} \mathrm{F}\right) \\
\end{array}$ & $\begin{array}{l}\text { LWC } \\
\left(\mathrm{g} / \mathrm{m}^{3}\right)\end{array}$ & $\begin{array}{l}\text { MVD } \\
(\mu \mathrm{m})\end{array}$ & $\begin{array}{c}\text { Ice Accretion } \\
\text { Time } \\
\text { (min) }\end{array}$ \\
\hline 071701.01_LE_1_T & Complete Scallop Condition & 4 & 250 & 25 & 0.68 & 20 & 10 \\
\hline 071701.02_LE_1_T & Complete Scallop Condition & 4 & 250 & 25 & 0.68 & 20 & 10 \\
\hline 071701.03_LE_2_T & Incomplete Scallop Condition & 4 & 150 & 25 & 0.65 & 20 & 10 \\
\hline 071701.04_LE_3_T & $\begin{array}{c}\text { Run based on scaled Condition } 2 \\
\text { for run in } 2 \mathrm{D} \text { table }\end{array}$ & 6 & 201.3 & 11.7 & 0.51 & 14.5 & 5.0 \\
\hline 071701.05_LE_2_T & SLD Condition A & 4 & 172.6 & 25 & 0.6 & 70 & 10 \\
\hline 071701.06_LE_2_T & Incomplete Scallop Condition & 4 & 150 & 25 & 0.65 & 20 & 10 \\
\hline 071801.01_LE_1_T & SLD Condition C & 4 & 172.62 & 25 & 1.0 & 175 & 22.5 \\
\hline 071801.02_LE_1_T & $\begin{array}{l}22.5 \text { minute failed ice protection } \\
\text { App C }\end{array}$ & 4 & 150 & 27 & 0.46 & 20 & 22.5 \\
\hline 071801.03_LE_2_T & $\begin{array}{l}\text { Complete Scallop Condition } \\
\text { long ice accretion time }\end{array}$ & 4 & 250 & 25 & 0.68 & 20 & 22.5 \\
\hline 071801.04_LE_3_T & SLD Condition D & 4 & 172.62 & 30 & 1.0 & 175 & 15 \\
\hline 071801.05_LE_3_T & $\begin{array}{l}\text { Complete Scallop Condition } \\
\text { short ice accretion time }\end{array}$ & 4 & 250 & 25 & 0.68 & 20 & 2 \\
\hline $\begin{array}{l}\text { 071901.01_LE_1_M } \\
\text { 071901.01_LE_1_B }\end{array}$ & SLD Condition B & 4 & 172.6 & 25 & 1.0 & 175 & 22.5 \\
\hline $\begin{array}{l}\text { 071901.02_LE_1_M } \\
071901.02 \text { LE_1_B }\end{array}$ & $\begin{array}{l}22.5 \text { minute failed ice protection } \\
\text { App C }\end{array}$ & 4 & 150 & 27 & 0.46 & 20 & 22.5 \\
\hline $\begin{array}{l}\text { 071901.03_LE_2_M } \\
\text { 071901.03_LE_2_B }\end{array}$ & $\begin{array}{l}\text { Complete Scallop Condition } \\
\text { long ice accretion time }\end{array}$ & 4 & 250 & 25 & 0.68 & 20 & 22.5 \\
\hline $\begin{array}{l}\text { 071901.04_LE_2_M } \\
\text { 071901.04_LE_2_B }\end{array}$ & Incomplete Scallop Condition & 4 & 150 & 25 & 0.65 & 20 & 10 \\
\hline $\begin{array}{l}\text { 071901.05_LE_3_M } \\
\text { 071901.05_LE_3_B }\end{array}$ & Complete Scallop Condition & 4 & 250 & 25 & 0.68 & 20 & 10 \\
\hline $\begin{array}{l}\text { 072001.01_LE_1_M } \\
\text { 072001.01_LE_1_B }\end{array}$ & $\begin{array}{c}\text { Run based on scaled Condition } 2 \\
\text { for run in } 2 \mathrm{D} \text { table }\end{array}$ & 6 & 201.3 & 11.7 & 0.51 & 14.5 & 5.0 \\
\hline $\begin{array}{l}\text { 072001.02_LE_1_M } \\
\text { 072001.02_LE_1_B }\end{array}$ & $\begin{array}{c}\text { Run based on scaled Condition } 2 \\
\text { for run in } 2 \mathrm{D} \text { table } \\
\end{array}$ & 6 & 201.3 & 11.7 & 0.51 & 14.5 & 5.0 \\
\hline $\begin{array}{l}\text { 072001.03_LE_2_M } \\
072001.03 \text { LE_2_B }\end{array}$ & $\begin{array}{l}\text { Complete Scallop Condition } \\
\text { short ice accretion time }\end{array}$ & 4 & 250 & 25 & 0.68 & 20 & 2 \\
\hline $\begin{array}{l}\text { 072001.04_LE_3_M } \\
\text { 072001.04_LE_3_B }\end{array}$ & $\begin{array}{l}\text { Complete Scallop Condition } \\
\text { long ice accretion time }\end{array}$ & 4 & 250 & 25 & 0.68 & 20 & 22.5 \\
\hline $\begin{array}{l}\text { 072001.05_LE_3_M } \\
072001.05 \text { LE_3_B }\end{array}$ & $\begin{array}{l}\text { Substitute condition to avoid } \\
\text { losing the ice accretion }\end{array}$ & 4 & 225 & 25 & 0.89 & 20 & 22.5 \\
\hline
\end{tabular}

Table 2. Test Matrix with all the runs conducted in the IRT 


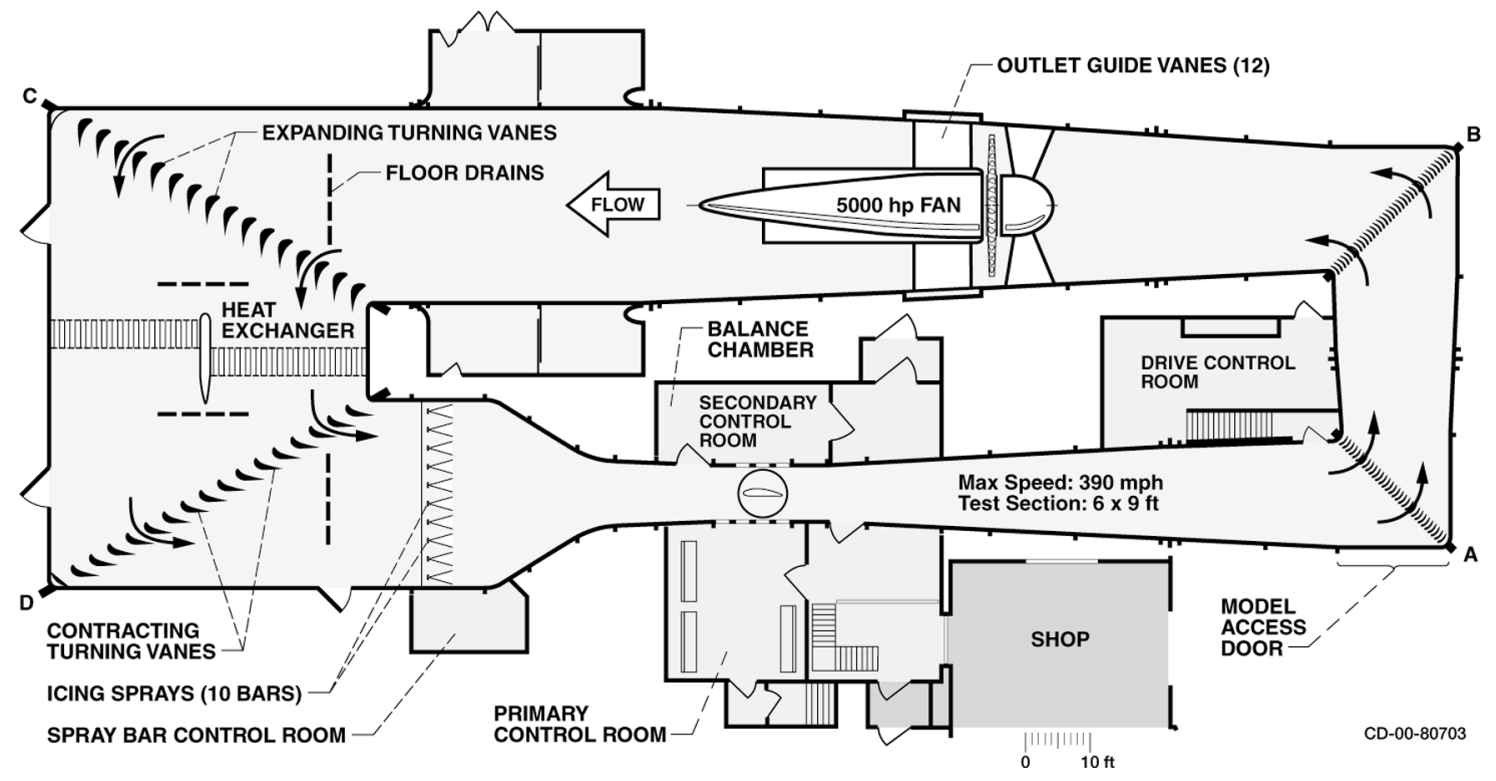

Figure 1. NASA Glenn Icing Research Tunnel, Plan view

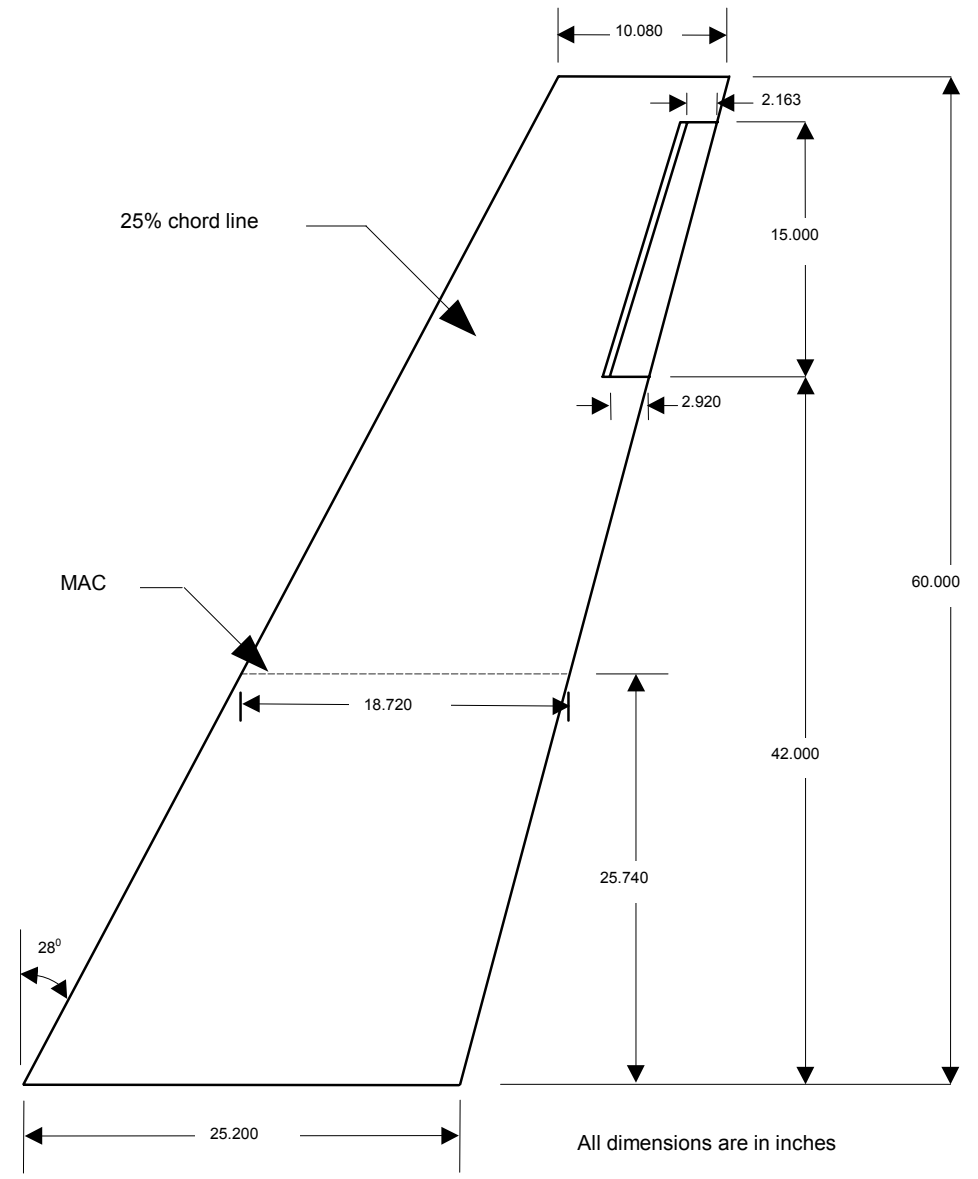

Figure 2. Dimensions and geometry for the GLC-305 airfoil 


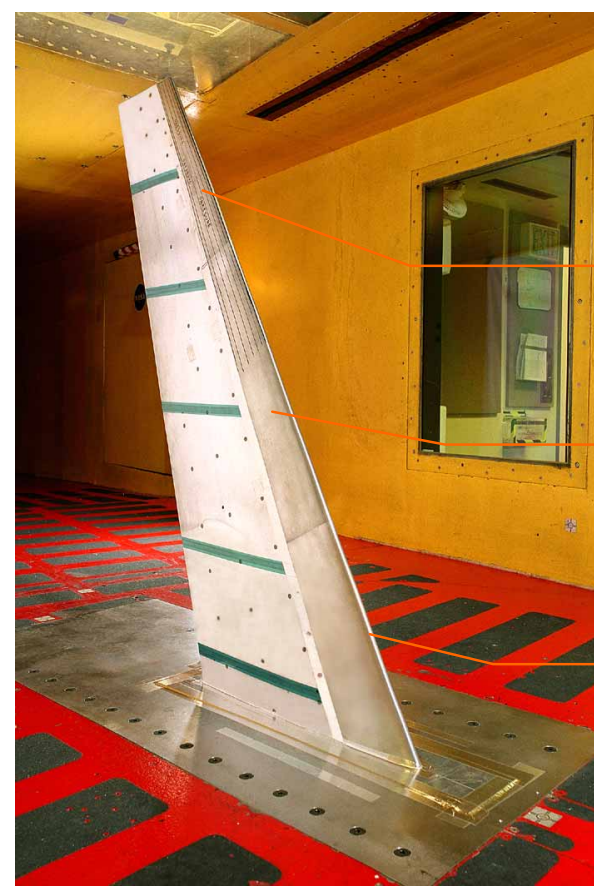

Figure 3. Airfoil in the low position. Removable leading edges can be observed
Top removable leading edge

Middle removable leading edge

Bottom removable leading edge

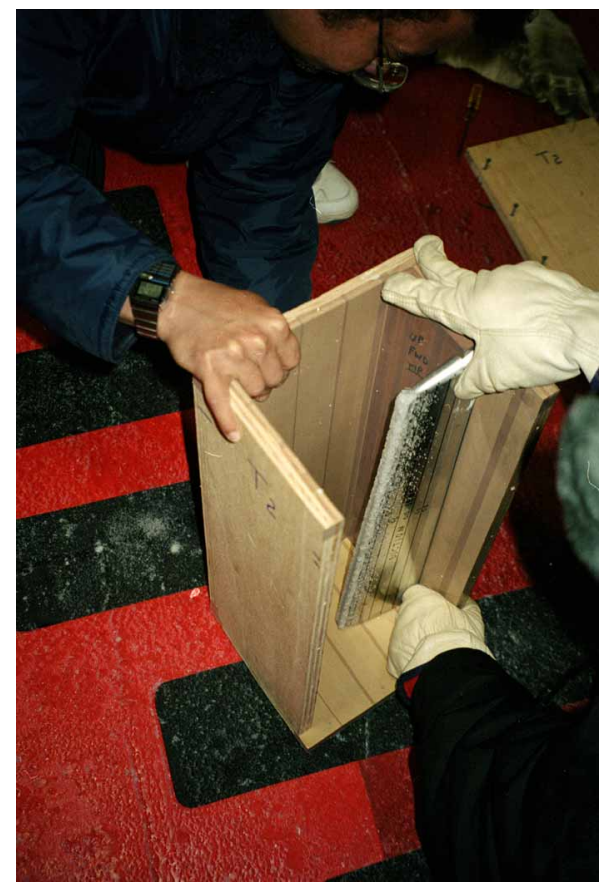

Figure 5. Leading edge attached to the inside of the wooden box.

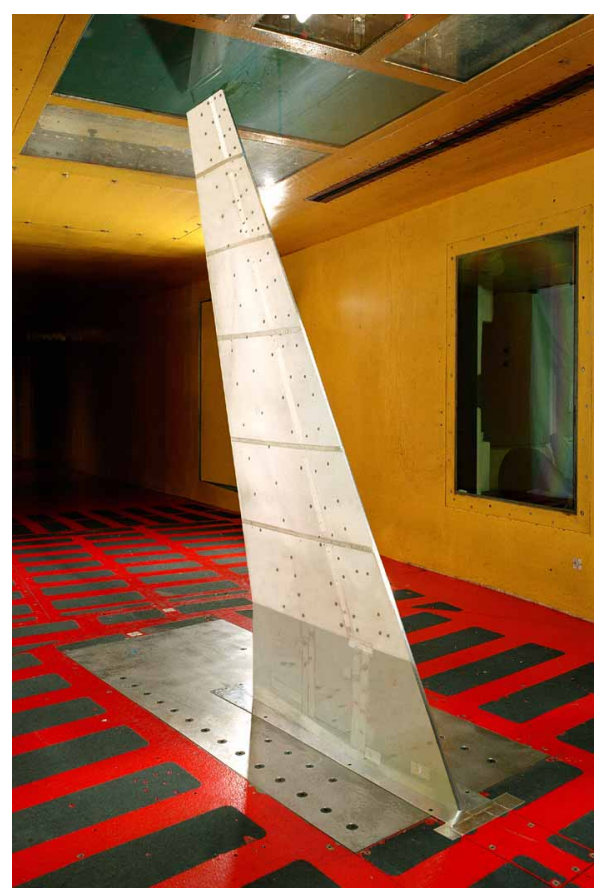

Figure 4. Airfoil in the high position

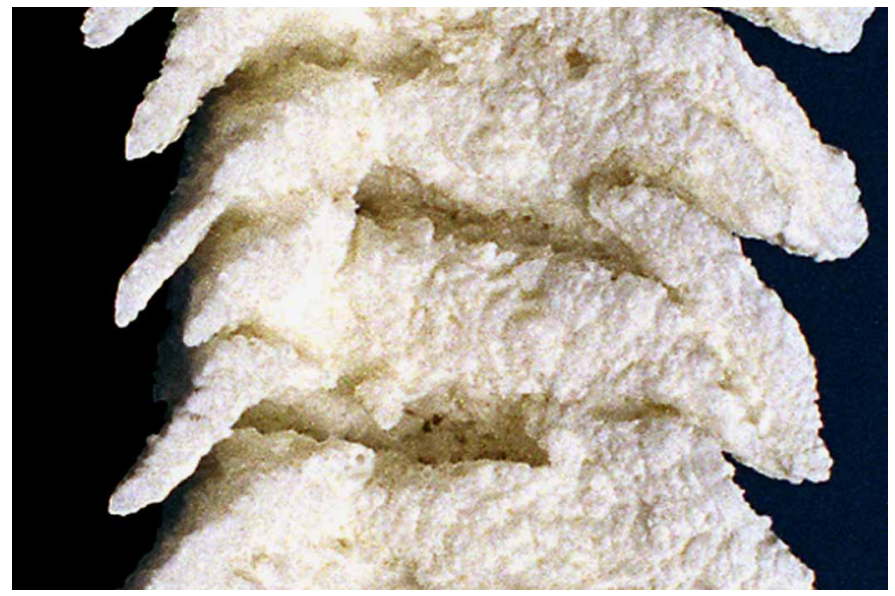

Figure 6. Close-up picture of casting obtained from the ice accretion shown in figure 23. Run number 072001.05_LE_3_M, icing conditions: $\mathrm{AOA}=4^{\circ}, \mathrm{V}=225 \mathrm{mph}, \mathrm{T}_{\text {total }}=25^{\circ} \mathrm{F}, \mathrm{LWC}=$ $0.89 \mathrm{~g} / \mathrm{m}^{3}, M V D=20 \mu \mathrm{m}, \tau=22.5 \mathrm{~min}$. Direction of flow is from bottom to top. 


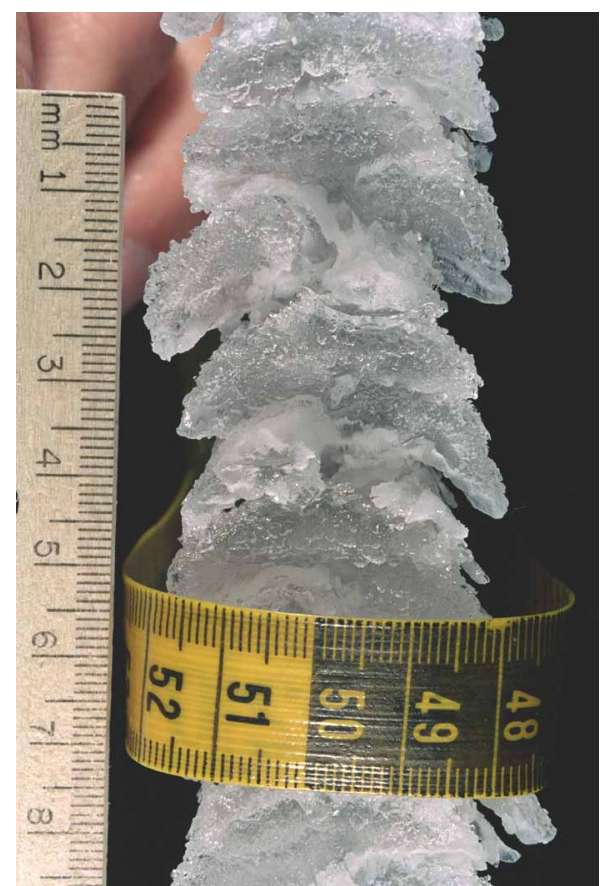

Figure 7. Front view of ice accretion on the Top leading edge. Ice accretion is a complete scallop. Run number 071701.02 LE 1_T, icing conditions: $\mathrm{AOA}=4^{\circ}, \mathrm{V}=250 \mathrm{mph}, \mathrm{T}_{\text {total }}=25^{\circ} \mathrm{F}$, $\mathrm{LWC}=0.68 \mathrm{~g} / \mathrm{m}^{3}, M V D=20 \mu \mathrm{m}, \tau=10 \mathrm{~min}$. Direction of flow is from bottom to top; scale of ruler is in centimeters, smallest division $1 \mathrm{~mm}$.

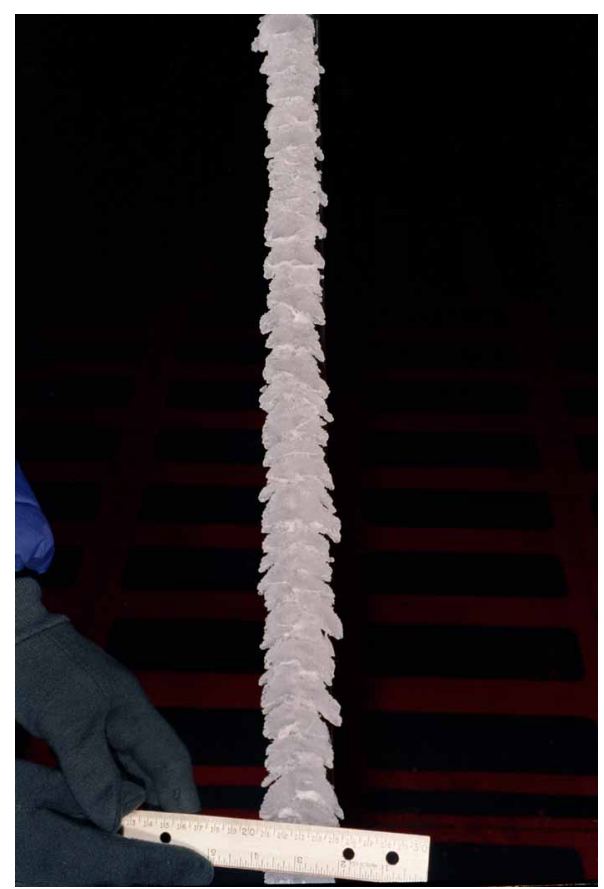

Figure 9. Front view of the complete ice accretion on the Top leading edge. Run number 071701.02_LE_1_T, icing conditions: $\mathrm{AOA}=4^{\circ}, \mathrm{V}=250 \mathrm{mph}, \mathrm{T}_{\text {total }}=25^{\circ} \mathrm{F}, \mathrm{LWC}=$ $0.68 \mathrm{~g} / \mathrm{m}^{3}, \mathrm{MVD}=20 \mu \mathrm{m}, \tau=10 \mathrm{~min}$. Direction of flow is from bottom to top; scale of ruler is in centimeters, smallest division $1 \mathrm{~mm}$.

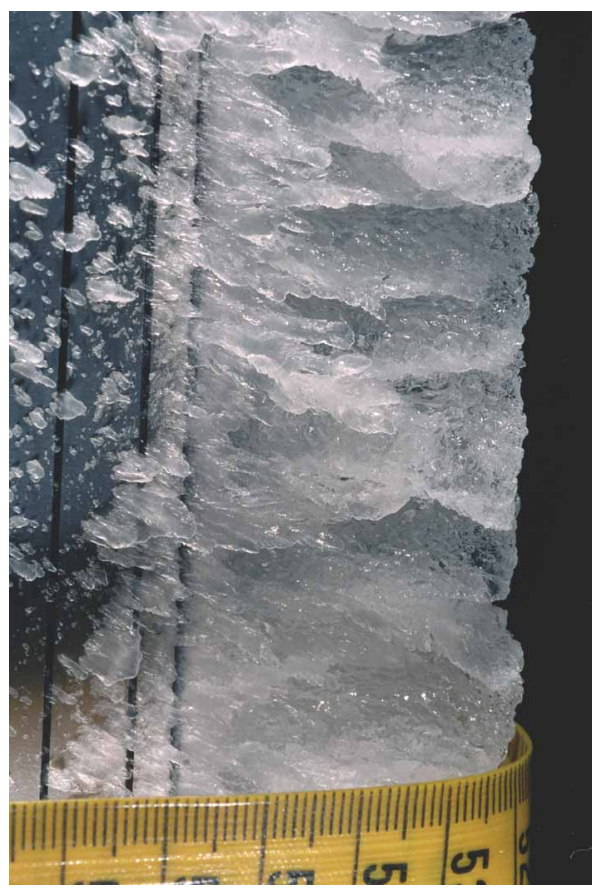

Figure 8. Side view of ice accretion on the pressure side of the Top leading edge. Ice accretion is a complete scallop. Run number 071701.02_LE_1_T, icing conditions: $A O A=4^{\circ}$, $\mathrm{V}=250 \mathrm{mph}, \overline{\mathrm{T}}_{\text {total }}=25^{\circ} \mathrm{F}, \mathrm{LWC}=0.68 \mathrm{~g} / \mathrm{m}^{3}, \mathrm{MVD}$ $=20 \mu \mathrm{m}, \tau=10 \mathrm{~min}$. Direction of flow is from bottom to top; scale of ruler is in centimeters, smallest division $1 \mathrm{~mm}$.

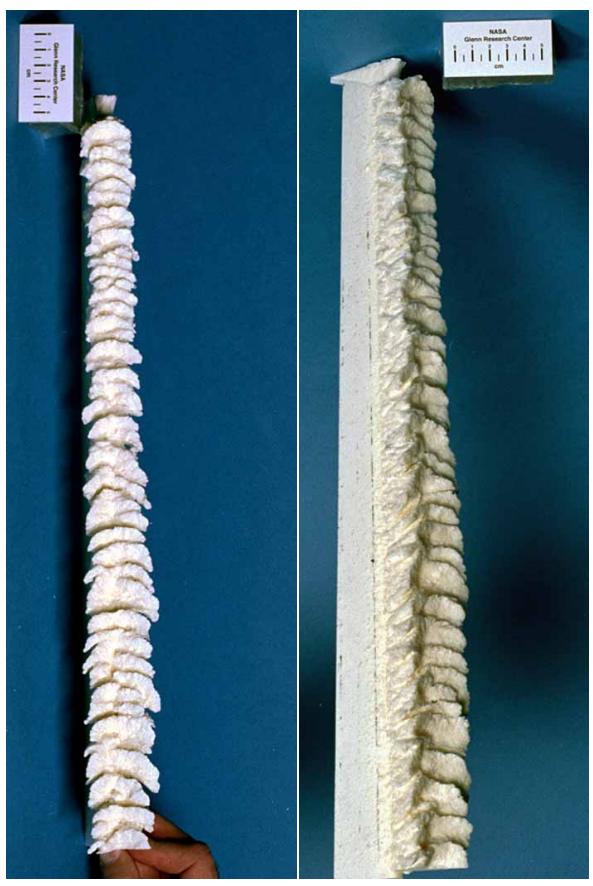

Figure 10. Front and side views of casting from the ice accretion on the Top leading edge. Run number 071701.02_LE_1_T, icing conditions: $A O A=4^{\circ}, V=250 \mathrm{mph}, \mathrm{T}_{\text {total }}=25^{\circ} \mathrm{F}$, $\mathrm{LWC}=0.68 \mathrm{~g} / \mathrm{m}^{3}, \mathrm{MVD}=20 \mu \mathrm{m}, \tau=10 \mathrm{~min}$. Direction of flow is from bottom to top; scale of ruler is in centimeters, smallest division 0.5 centimeters. 


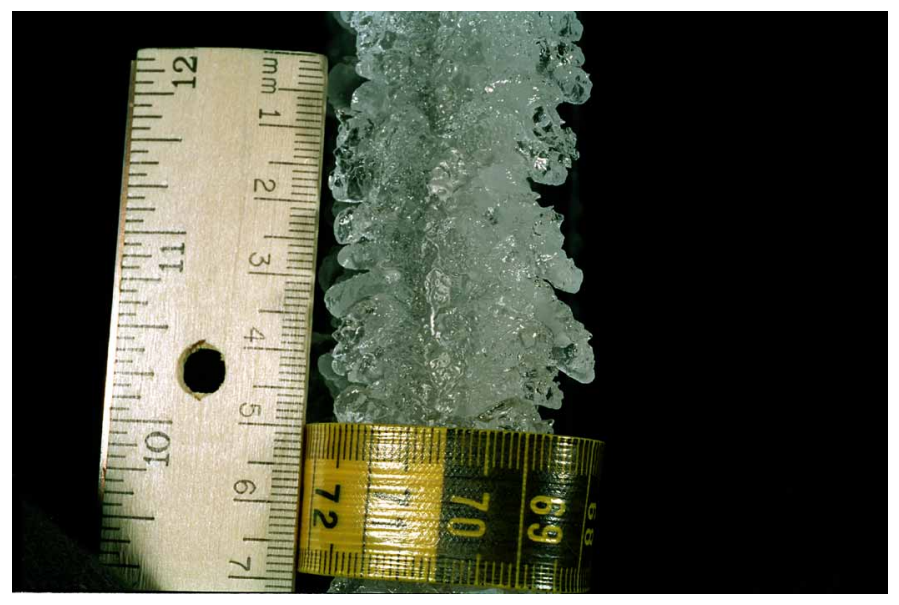

Figure 11. Front view of ice accretion on the Bottom leading edge. Ice accretion is an incomplete scallop. Run number 071901.04_LE_2_B, icing conditions: $A O A=4^{\circ}$, $\mathrm{V}=150 \mathrm{mph}, \mathrm{T}_{\text {total }}=25^{\circ} \mathrm{F}, \mathrm{LWC}=0.65 \mathrm{~g} / \mathrm{m}^{3}, \mathrm{MVD}$ $=20 \mu \mathrm{m}, \tau=10 \mathrm{~min}$. Direction of flow is from bottom to top; scale of ruler is in centimeters, smallest division $1 \mathrm{~mm}$.

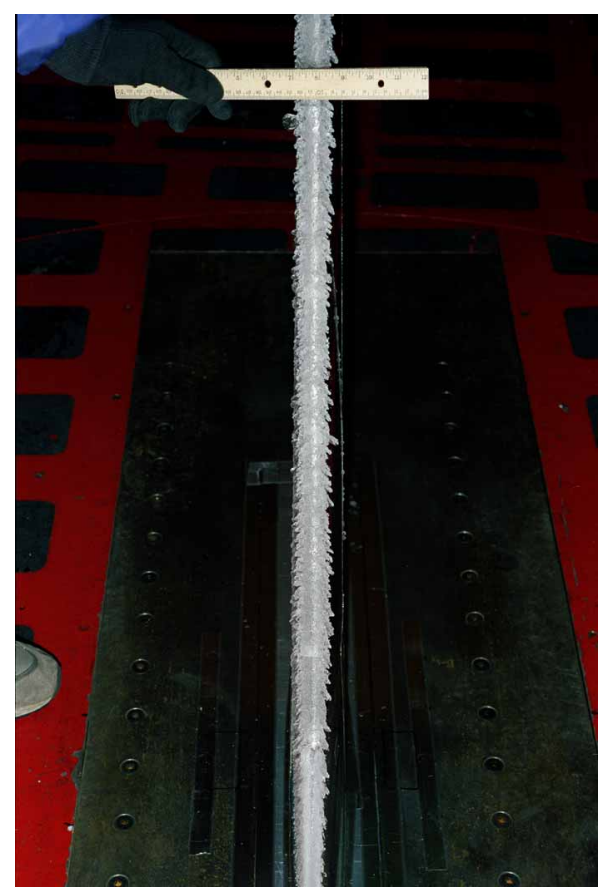

Figure 13. Front view of the complete ice accretion on the Bottom leading edge. Run number 071901.04_LE_2_B, icing conditions: $\mathrm{AOA}=4^{\circ}, \mathrm{V}=150 \mathrm{mph}, \mathrm{T}_{\text {total }}=25^{\circ} \mathrm{F}, \mathrm{LWC}=$ $0.65 \mathrm{~g} / \mathrm{m}^{3}, \mathrm{MVD}=20 \mu \mathrm{m}, \tau=10 \mathrm{~min}$. Direction of flow is from bottom to top; scale of ruler is in centimeters, smallest division $1 \mathrm{~mm}$.

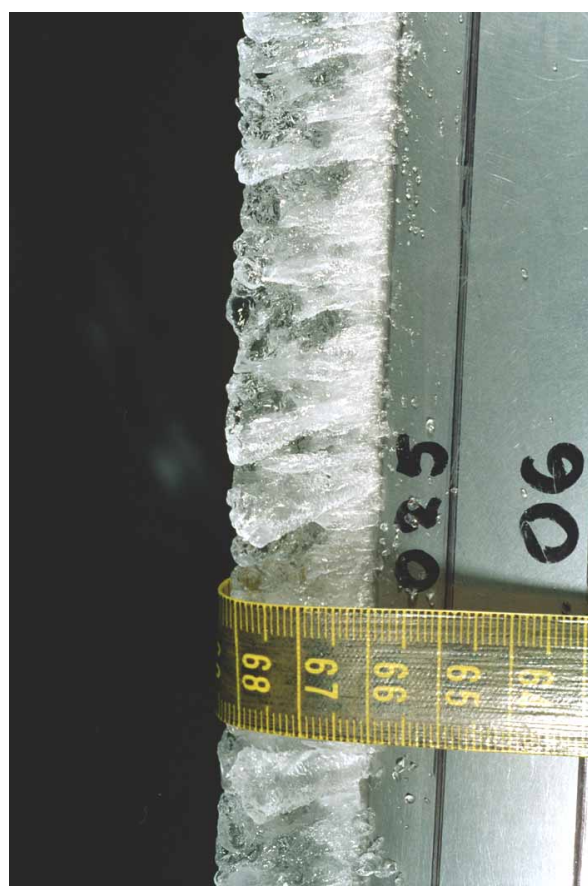

Figure 12. Side view of ice accretion on the suction side of the Bottom leading edge. Ice accretion is an incomplete scallop. Run number 071901.04_LE_2_B, icing conditions: $A O A=4^{\circ}$, $\mathrm{V}=150 \mathrm{mph}, \mathrm{T}_{\text {total }}=25^{\circ} \mathrm{F}, \mathrm{LWC}=0.65 \mathrm{~g} / \mathrm{m}^{3}, \mathrm{MVD}$ $=20 \mu \mathrm{m}, \tau=10 \mathrm{~min}$. Direction of flow is from bottom to top; scale of ruler is in centimeters, smallest division $1 \mathrm{~mm}$.

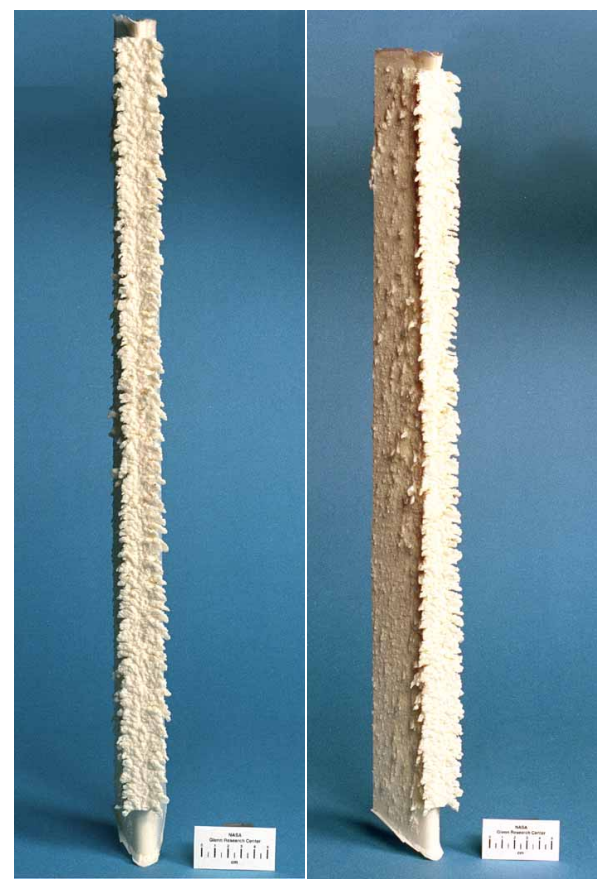

Figure 14. Front and side views of casting from the ice accretion on the Bottom leading edge. Run number 071901.04_LE_2_B, icing conditions: $\mathrm{AOA}=4^{\circ}, \mathrm{V}=150 \mathrm{mph}, \mathrm{T}_{\text {total }}=25^{\circ} \mathrm{F}$, $\mathrm{LWC}=0.65 \mathrm{~g} / \mathrm{m}^{3}, \mathrm{MVD}=20 \mu \mathrm{m}, \tau=10 \mathrm{~min}$. Direction of flow is from bottom to top; scale of ruler is in centimeters, smallest division 0.5 centimeters. 


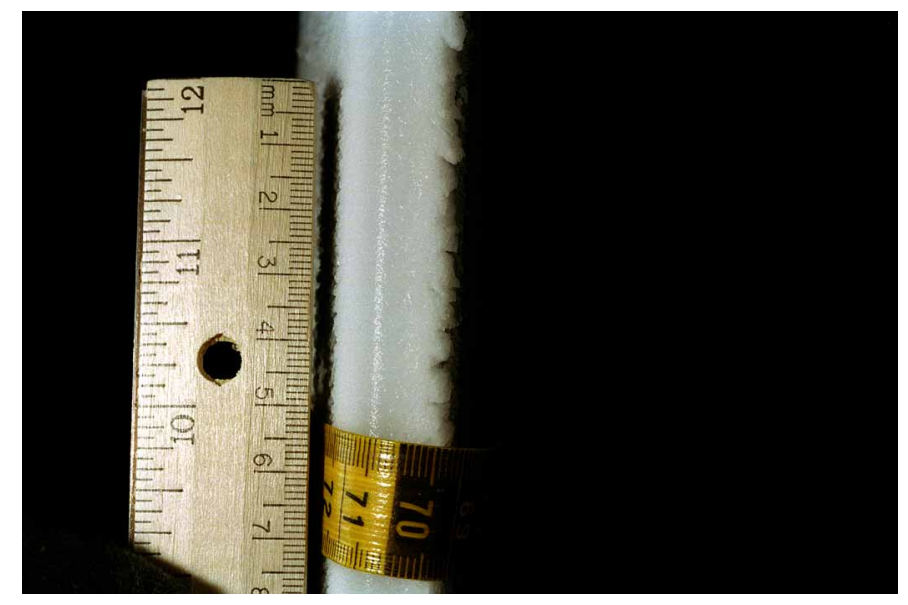

Figure 15. Front view of ice accretion on the Bottom leading edge. Ice accretion is a no scallop. Run number 072001.02_LE_1_B, icing conditions: $\mathrm{AOA}=6^{\circ}, \mathrm{V}=201 . \overline{\mathrm{mph}}, \mathrm{T}_{\text {total }}=$ $11.7^{\circ} \mathrm{F}, \mathrm{LWC}=0.51 \mathrm{~g} / \mathrm{m}^{3}, \mathrm{MVD}=14.5 \mu \mathrm{m}, \tau=$ $5 \mathrm{~min}$. Direction of flow is from bottom to top; scale of ruler is in centimeters, smallest division $1 \mathrm{~mm}$.

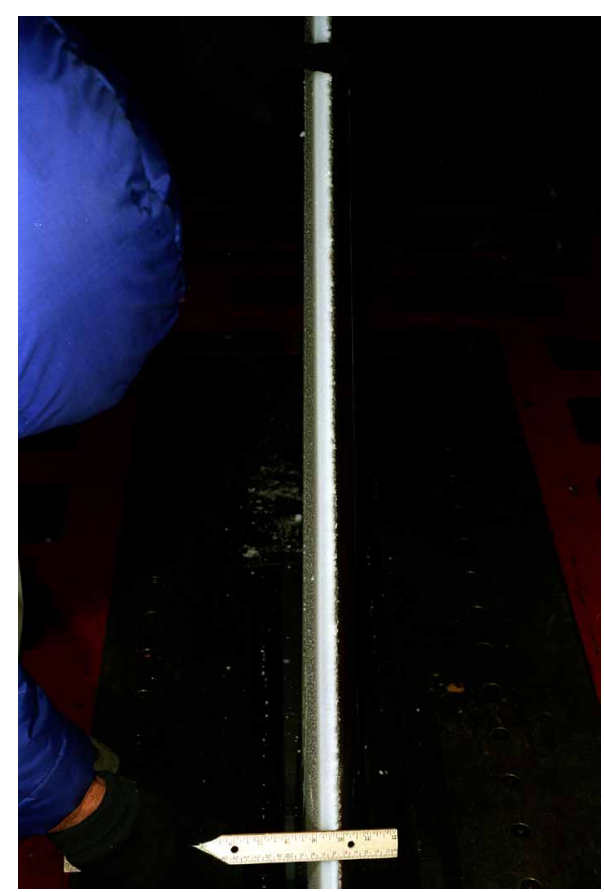

Figure 17. Front view of the complete ice accretion on the Bottom leading edge. Run number 072001.02_LE_1_B, icing conditions: $\mathrm{AOA}=6^{\circ}, \mathrm{V}=201.3 \mathrm{mph}, \mathrm{T}_{\text {total }}=11.7^{\circ} \mathrm{F}, \mathrm{LWC}=$ $0.51 \mathrm{~g} / \mathrm{m}^{3}, \mathrm{MVD}=14.5 \mu \mathrm{m}, \tau=5 \mathrm{~min}$. Direction of flow is from bottom to top; scale of ruler is in centimeters, smallest division $1 \mathrm{~mm}$.

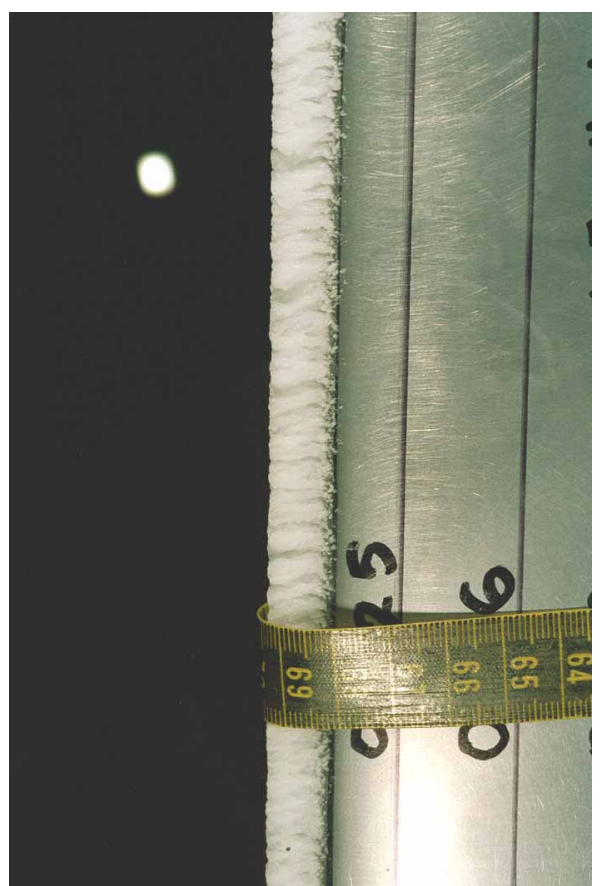

Figure 16. Side view of ice accretion on the suction side of the Bottom leading edge. Ice accretion is a no scallop. Run number 072001.02_LE_1_B, icing conditions: $A O A=6^{\circ}$, $\mathrm{V}=201.3 \mathrm{mph}, \mathrm{T}_{\text {total }}=11.7^{\circ} \mathrm{F}, \mathrm{LWC}=0.51 \mathrm{~g} / \mathrm{m}^{3}$, MVD $=14.5 \mu \mathrm{m}, \tau=5 \mathrm{~min}$. Direction of flow is from bottom to top; scale of ruler is in centimeters, smallest division $1 \mathrm{~mm}$.

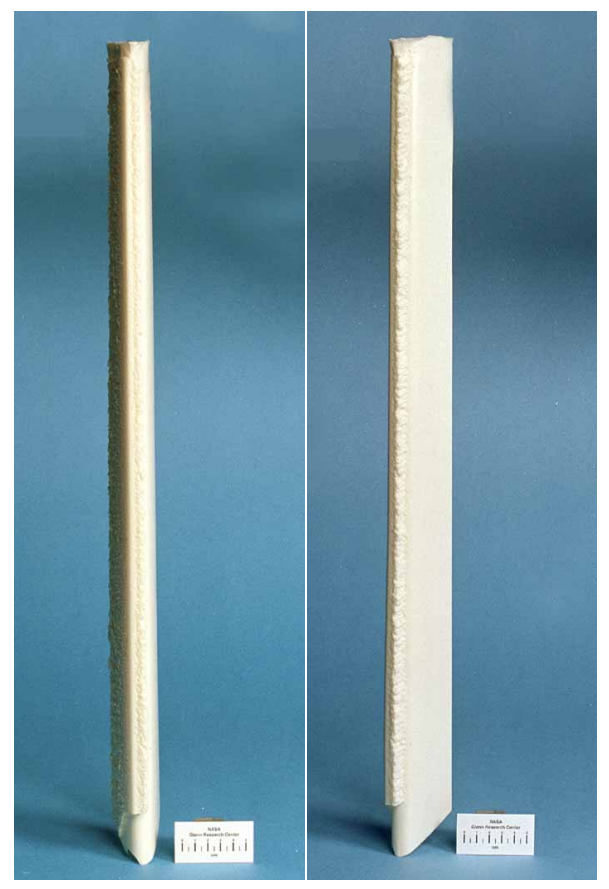

Figure 18. Front and side views of casting from the ice accretion on the Bottom leading edge. Run number 072001.02_LE_1_B, icing conditions: $\mathrm{AOA}=6^{\circ}, \mathrm{V}=201.3 \mathrm{mph}, \mathrm{T}_{\text {total }}=$ $11.7^{\circ} \mathrm{F}, \mathrm{LWC}=0.51 \mathrm{~g} / \mathrm{m}^{3}, \mathrm{MVD}=14.5 \mu \mathrm{m}, \tau=$ $5 \mathrm{~min}$. Direction of flow is from bottom to top; scale of ruler is in centimeters, smallest division 0.5 centimeters. 


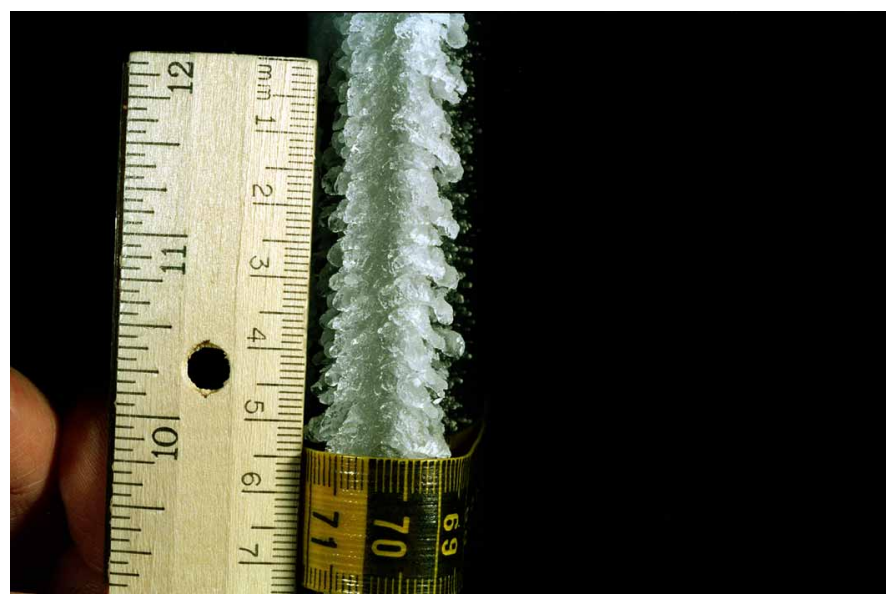

Figure 19. Front view of ice accretion on the Middle leading edge. Run number 072001.03_LE_2_M, icing conditions: $A O A=4^{\circ}$, $\mathrm{V}=250 \mathrm{mph}, \mathrm{T}_{\text {total }}=25^{\circ} \mathrm{F}, \mathrm{LWC}=0.68 \mathrm{~g} / \mathrm{m}^{3}, \mathrm{MVD}$ $=20 \mu \mathrm{m}, \tau=2 \mathrm{~min}$. Direction of flow is from bottom to top; scale of ruler is in centimeters, smallest division $1 \mathrm{~mm}$.

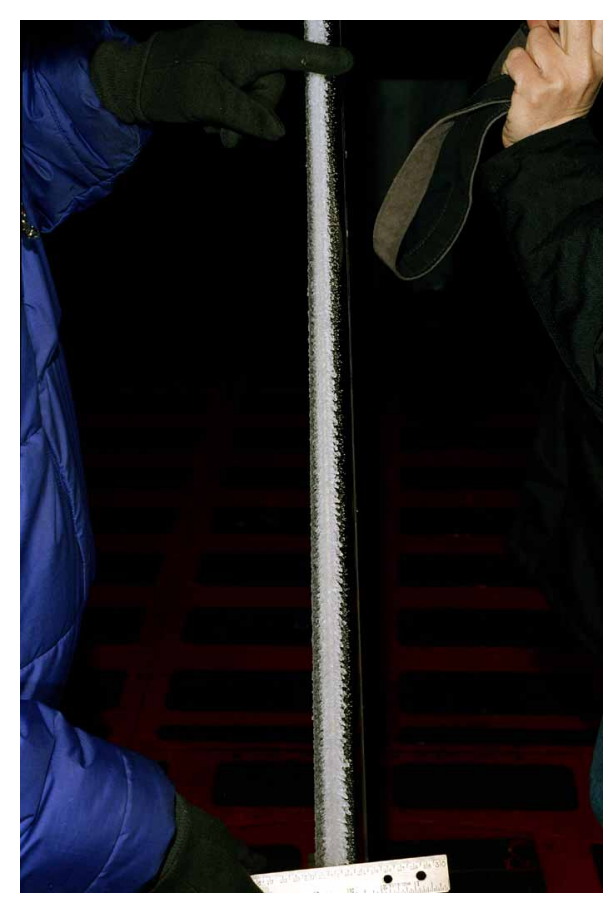

Figure 21. Front view of the complete ice accretion on the Middle leading edge. Run number 072001.03_LE_2_M, icing conditions: $\mathrm{AOA}=4^{\circ}, \mathrm{V}=250 \mathrm{mph}, \mathrm{T}_{\text {total }}=25^{\circ} \mathrm{F}, \mathrm{LWC}=$ $0.68 \mathrm{~g} / \mathrm{m}^{3}, M V D=20 \mu \mathrm{m}, \tau=2 \mathrm{~min}$. Direction of flow is from bottom to top; scale of ruler is in centimeters, smallest division $1 \mathrm{~mm}$.

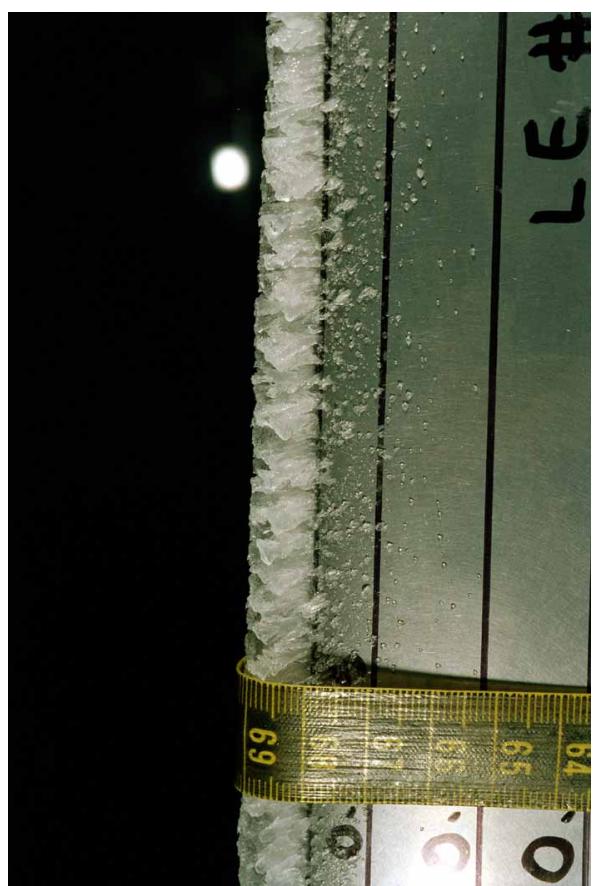

Figure 20. Side view of ice accretion on the suction side of the Middle leading edge. Run number 072001.03_LE_2_M, icing conditions: $A O A=4^{\circ}, V=250 \mathrm{mph}, T_{\text {total }}=25^{\circ} \mathrm{F}, L W C=$ $0.68 \mathrm{~g} / \mathrm{m}^{3}, M V D=20 \mu \mathrm{m}, \tau=2 \mathrm{~min}$. Direction of flow is from bottom to top; scale of ruler is in centimeters, smallest division $1 \mathrm{~mm}$.

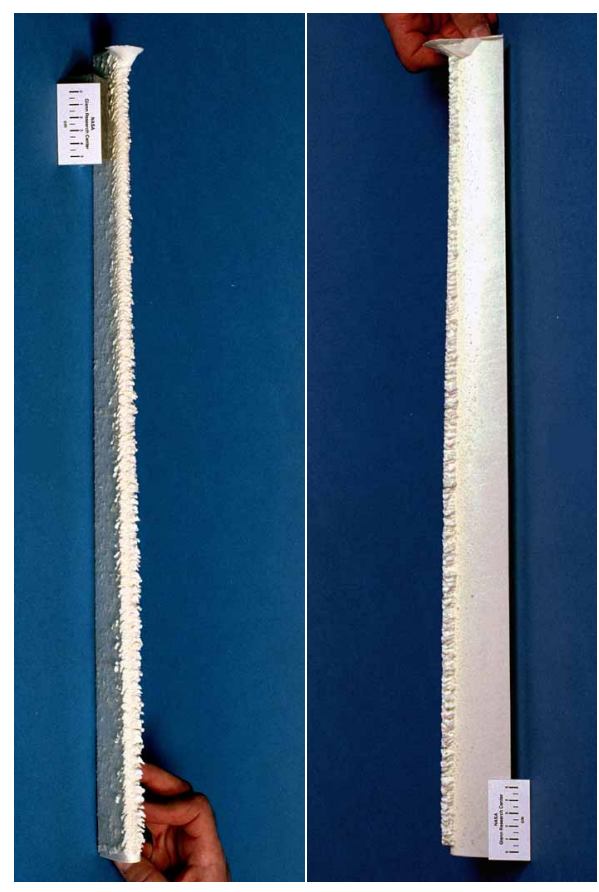

Figure 22. Front and side views of casting from the ice accretion on the Middle leading edge. Run number 072001.03_LE_2_M, icing conditions: $A O A=4^{\circ}, V=250 \mathrm{mph}, \mathrm{T}_{\text {total }}=25^{\circ} \mathrm{F}$, $\mathrm{LWC}=0.68 \mathrm{~g} / \mathrm{m}^{3}, \mathrm{MVD}=20 \mu \mathrm{m}, \tau=2 \mathrm{~min}$. Direction of flow is from bottom to top; scale of ruler is in centimeters, smallest division 0.5 centimeters. 


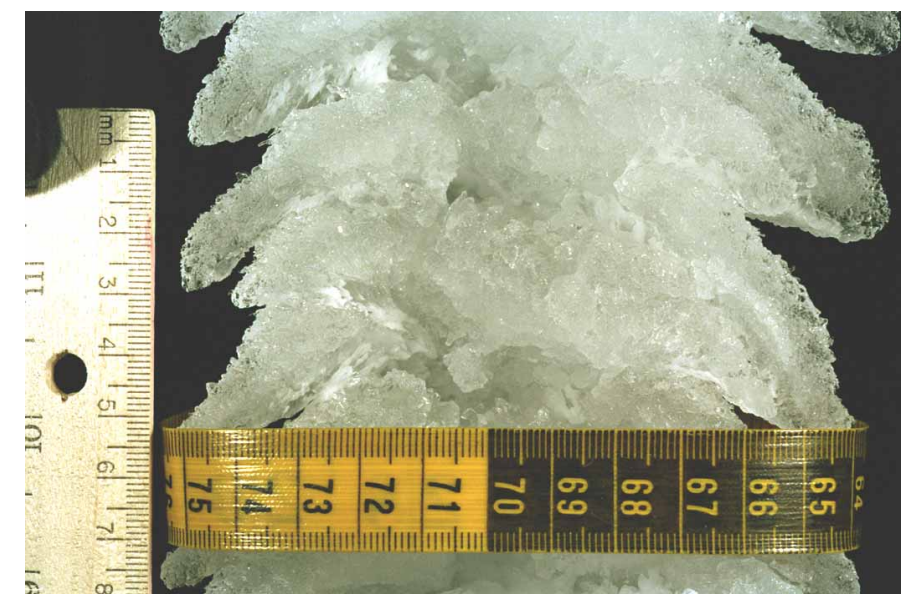

Figure 23. Front view of ice accretion on the Middle leading edge. Ice accretion is a complete scallop. Run number 072001.05 LE 3 M, icing conditions: $\mathrm{AOA}=4^{\circ}, \mathrm{V}=225 \mathrm{mph}, \mathrm{T}_{\text {total }}=25^{\circ} \mathrm{F}$, $\mathrm{LWC}=0.89 \mathrm{~g} / \mathrm{m}^{3}, \mathrm{MVD}=20 \mu \mathrm{m}, \tau=22.5 \mathrm{~min}$. Direction of flow is from bottom to top; scale of ruler is in centimeters, smallest division $1 \mathrm{~mm}$.

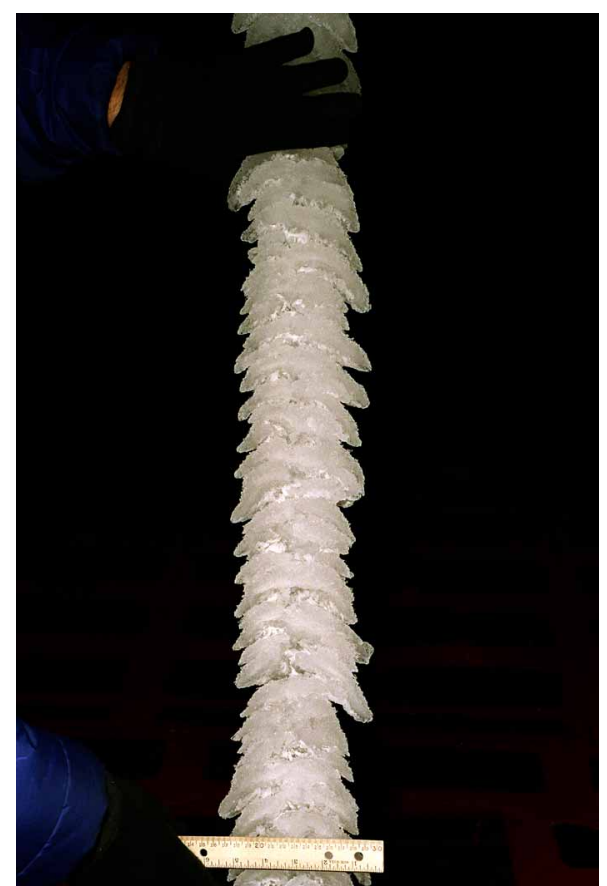

Figure 25. Front view of the complete ice accretion on the Middle leading edge. Run number 072001.05_LE_3_M, icing conditions: $A O A=4^{\circ}, V=225 \mathrm{mph}, \mathrm{T}_{\text {total }}=25^{\circ} \mathrm{F}, \mathrm{LWC}=$ $0.89 \mathrm{~g} / \mathrm{m}^{3}, \mathrm{MVD}=20 \mu \mathrm{m}, \tau=22.5 \mathrm{~min}$. Direction of flow is from bottom to top; scale of ruler is in centimeters, smallest division $1 \mathrm{~mm}$.

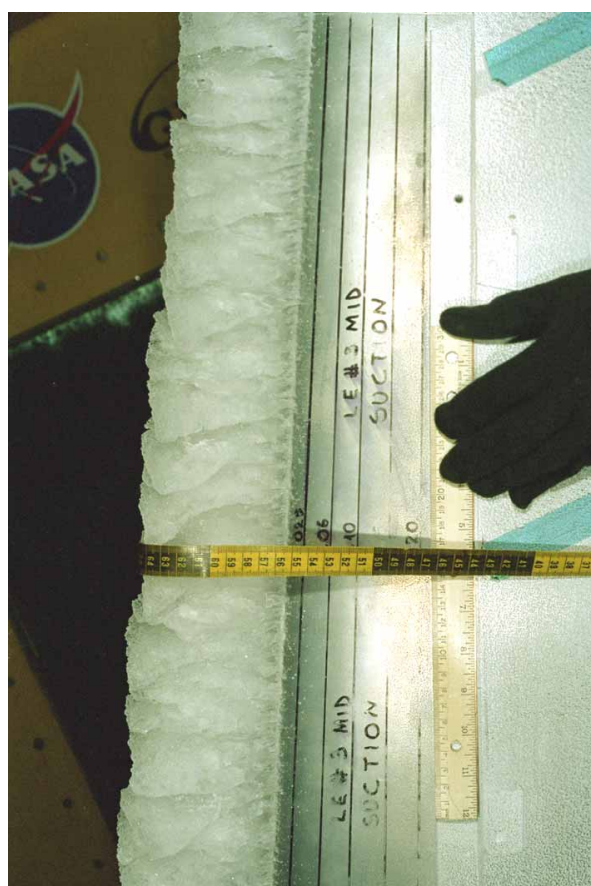

Figure 24. Side view of ice accretion on the suction side of the Middle leading edge. Ice accretion is a complete scallop. Run number 072001.05_LE_3_M, icing conditions: $A O A=4^{\circ}$, $\mathrm{V}=225 \mathrm{mph}, \mathrm{T}_{\text {total }}=25^{\circ} \mathrm{F}, \mathrm{LWC}=0.89 \mathrm{~g} / \mathrm{m}^{3}, \mathrm{MVD}$ $=20 \mu \mathrm{m}, \tau=22.5 \mathrm{~min}$. Direction of flow is from bottom to top; scale of ruler is in centimeters, smallest division $1 \mathrm{~mm}$.

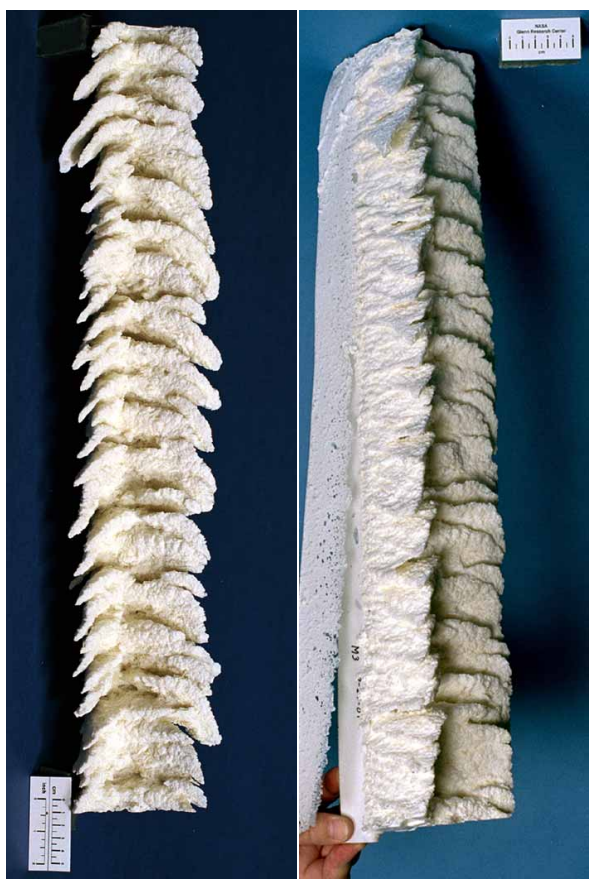

Figure 26. Front and side views of casting from the ice accretion on the Middle leading edge. Run number 072001.05_LE_3_M, icing conditions: $A O A=4^{\circ}, V=225 \mathrm{mph}, \mathrm{T}_{\text {total }}=25^{\circ} \mathrm{F}$, $\mathrm{LWC}=0.89 \mathrm{~g} / \mathrm{m}^{3}, \mathrm{MVD}=20 \mu \mathrm{m}, \tau=22.5 \mathrm{~min}$. Direction of flow is from bottom to top; scale of ruler is in centimeters, smallest division 0.5 centimeters. 


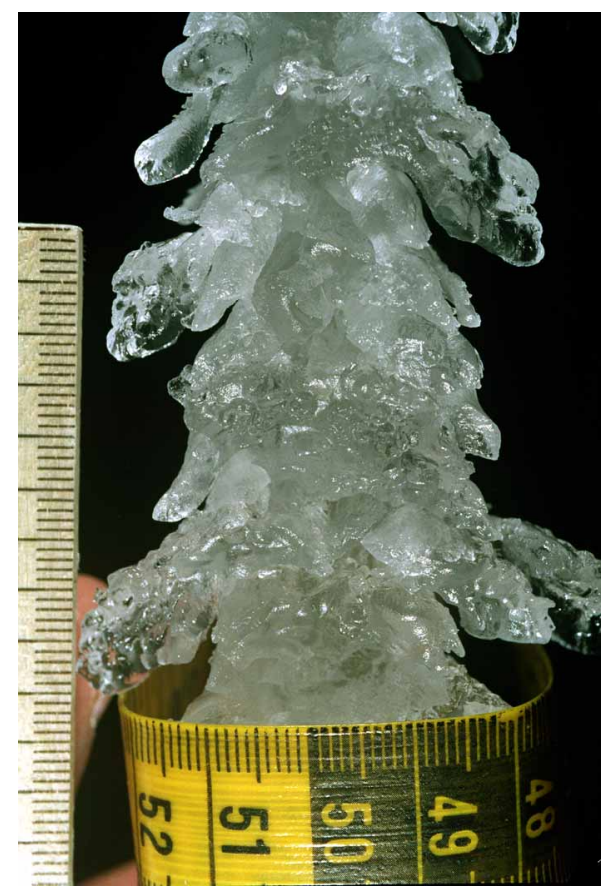

Figure 27. Front view of ice accretion on the Top leading edge. Run number 071801.02_LE_1_T, icing conditions: $A O A=4^{\circ}$, $\mathrm{V}=150 \mathrm{mph}, \mathrm{T}_{\text {total }}=27^{\circ} \mathrm{F}, \mathrm{LWC}=0.46 \mathrm{~g} / \mathrm{m}^{3}, \mathrm{MVD}$ $=20 \mu \mathrm{m}, \tau=22.5 \mathrm{~min}$. Direction of flow is from bottom to top; scale of ruler is in centimeters, smallest division $1 \mathrm{~mm}$.

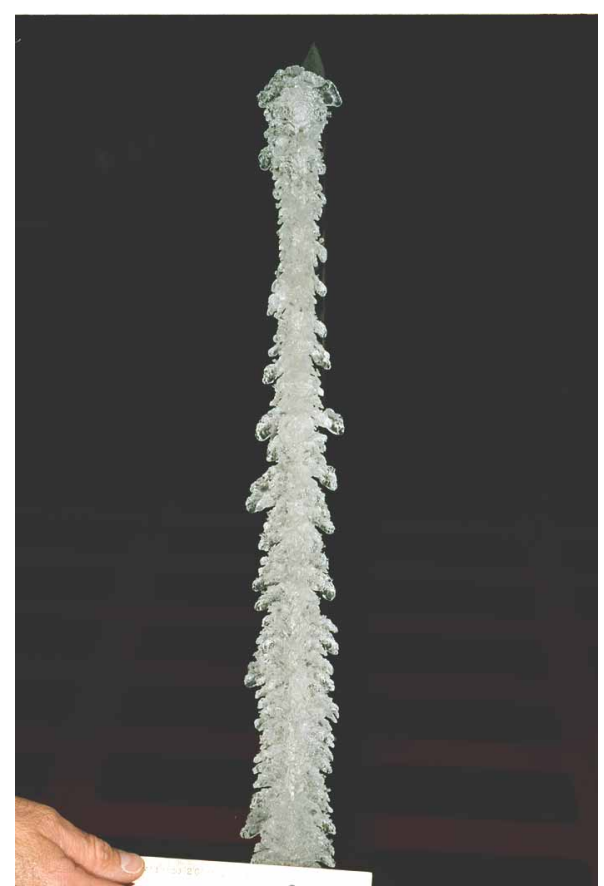

Figure 29. Front view of the complete ice accretion on the Top leading edge. Run number 071801.02_LE_1_T, icing conditions: $A O A=4^{\circ}, V=150 \mathrm{mph}, \mathrm{T}_{\text {total }}=27^{\circ} \mathrm{F}, \mathrm{LWC}=$ $0.46 \mathrm{~g} / \mathrm{m}^{3}, \mathrm{MVD}=20 \mu \mathrm{m}, \tau=22.5 \mathrm{~min}$. Direction of flow is from bottom to top; scale of ruler is in centimeters, smallest division $1 \mathrm{~mm}$.

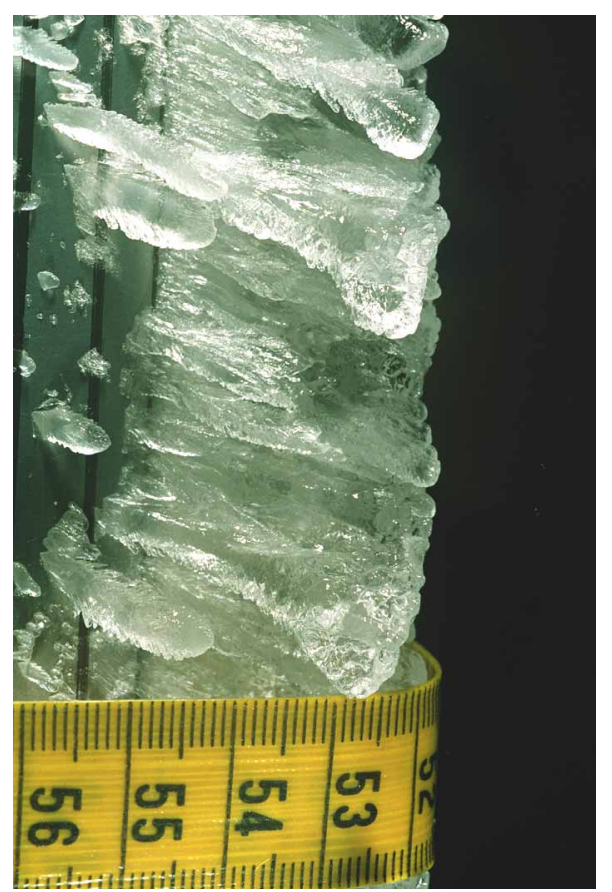

Figure 28. Side view of ice accretion on the pressure side of the Top leading edge. Run number 071801.02_LE_1_T, icing conditions: $A O A=4^{\circ}, V=150 \mathrm{mph}, T_{\text {total }}=27^{\circ} \mathrm{F}, L W C=$ $0.46 \mathrm{~g} / \mathrm{m}^{3}, \mathrm{MVD}=20 \mu \mathrm{m}, \tau=22.5 \mathrm{~min}$. Direction of flow is from bottom to top; scale of ruler is in centimeters, smallest division $1 \mathrm{~mm}$.

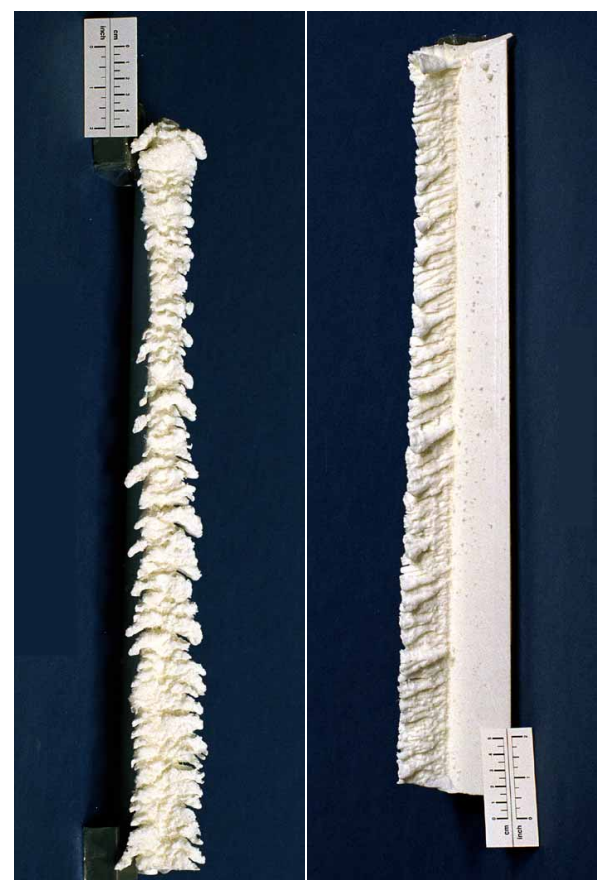

Figure 30. Front and side views of casting from the ice accretion on the Top leading edge. Run number 071801.02_LE_1_T, icing conditions: $\mathrm{AOA}=4^{\circ}, \mathrm{V}=150 \mathrm{mph}, \mathrm{T}_{\text {total }}=27^{\circ} \mathrm{F}$, $\mathrm{LWC}=0.46 \mathrm{~g} / \mathrm{m}^{3}, \mathrm{MVD}=20 \mu \mathrm{m}, \tau=22.5 \mathrm{~min}$. Direction of flow is from bottom to top; scale of ruler is in centimeters, smallest division 0.5 centimeters. 
